\title{
ASSESSMENT OF STAGE T1 (TNM 1997) FOR RENAL CELL CARCINOMA: IS RECOMMENDED THE SUBDIVISION IN T1A AND T1B?
}

\author{
MARCOS DALL'OGLIO, MIGUEL SROUGI, MARCELO MANGINI, EDUARDO RIBEIRO, \\ MÁRCIO FERRAZ, ADRIANA SAÑUDO, KÁTIA LEITE, LUCIANO NESRALLAH \\ Divisions of Urology and Statistics, Paulista School of Medicine, Federal University of \\ São Paulo (UNIFESP), São Paulo, SP, Brazil
}

\begin{abstract}
Introduction: Classification TNM 1997 defines renal cell carcinoma smaller than $7 \mathrm{~cm}$ and confined to the kidney as stage T1. Our goal is to discuss if tumors smaller than $4 \mathrm{~cm}$ have the same behavior characteristics then tumors between 4 and $7 \mathrm{~cm}$, to compose the same stage of the disease.

Materials and Methods: Retrospective assessment of 138 patients in stage T1 (TNM - 97), divided into 2 groups; group-1: composed of 65 patients $(47 \%)$ with tumors $<4 \mathrm{~cm}$, and group-2: composed of 73 patients $(53 \%)$ with tumors between 4 and $7 \mathrm{~cm}$. The following prognostic factors were assessed in the recurrence of the disease and survival of patients: nuclear degree, microvascular invasion, sarcomatous degeneration, and involved lymph nodes. Statistical evaluation has been accomplished through the log rank test, chi-square test, and Fisher's exact text.

Results: Average tumor size was $2.5 \mathrm{~cm}$ for group-1, and $5.3 \mathrm{~cm}$ for group-2. In group-2, there was the predominance of worse prognostic factors, with high-grade tumors $(\mathrm{p}=0.01)$ and presence of microvascular invasion $(\mathrm{p}=0.001)$. Sarcomatous tumors and involvement of lymph nodes did only happen in group-2. Disease-free survival for group-1, analyzed in the median period of 36 months, was $100 \%$, and for group 2 , in the median period of 31 months, was $81 \%(p=0.008$ ).

Conclusion: The results obtained allow the conclusion that the present stage T1 for renal cell carcinoma gathers tumors of different evolution, being therefore recommendable the stratification in T1a for tumors smaller than $4 \mathrm{~cm}$, and T1b for tumors between 4 and $7 \mathrm{~cm}$.
\end{abstract}

Key words: kidney; carcinoma, renal cell; neoplasm staging; prognosis; classification; survival Int Braz J Urol. 2003; 29: 106-12

\section{INTRODUCTION}

Renal cell carcinoma (RCC) is the third most common neoplasia of urinary tract. In last decades, with increased sensibility of imaging methods, the early diagnosis of this neoplasia has become more frequent, reaching up to $60 \%$ in the incidental form (1).

Due to the increase in the incidence of renal tumors, the urologist should be familiarized with the characteristics of this tumor, as well, as its evolution.
One of the first staging systems used was the one of Robson et al. (2), but the stage TNM presents a more detailed anatomic classification, and its use offers a common language for the treatment and prognostic evaluation of patients having RCC. Stage TNM was last modified in 1997 (3), nevertheless, there are proposals for a new modification (4-8).

We have retrospectively assessed 2 groups of patients, by comparing the group having tumors smaller than $4 \mathrm{~cm}$ with the group having tumors between 4 and $7 \mathrm{~cm}$, analyzing the differences of prog- 
nostic factors for the recurrence of disease and survival of patients.

\section{MATERIALS AND METHODS}

In the period between January 1988 and July 2002, 138 patients bearing RCC stage T1 (TNM 97), were operated by the same group of surgeons in 2 hospitals and were retrospectively assessed. Presurgical evaluation included ultrasonography, computer tomography of abdomen and/or magnetic resonance imaging and chest $\mathrm{x}$-ray. Post-surgical follow up varied between 2 and 138 months (median $=33$ months). Patients were asked about their participation in the study through post-informed consent, and afterwards, a retrospective analysis through patients' records data was accomplished. Clinical information collected included age, sex, side of tumoral kidney; time of diagnosis, surgical treatment (radical or conservative), pathologic examination, and post-surgical follow up. All pathologic material (slides and fragments embedded in paraffin) was revised in the light microscope by just one pathologist, being checked the tumoral diameter, cellular type, nuclear degree, presence of microvascular intra-tumoral invasion, and positive lymph nodes. In post-surgical follow up, the following examinations were accomplished: chest $\mathrm{x}$ ray, abdominal ultrasonography and/or computer tomography (interspersed) and hematological examinations at each 3 months during first year, every six months from second to fifth year, and annually after this period.

To assess the impact of tumoral diameter with factors of worse prognosis in the recurrence of the disease and survival of patients, they have been divided into 2 groups: a) group-1: tumors smaller than $4 \mathrm{~cm}$; b) group-2: tumors between 4 and $7 \mathrm{~cm}$.

Statistical analysis used was the log rank test for survival curves, chi-square test, and Fisher exact test to assess the difference between the 2 groups. $\mathrm{P}<0.05$ was considered statistically significant.

\section{RESULTS}

For the total of 138 patients, 103 men (75\%) and 35 women $(25 \%)$, the tumor was in the right kidney in 71 patients (51\%), in the left in 66 patients (48\%), and in both in one patient (1\%). For group-1, the surgery was conservative in $28(37 \%)$ cases, and radical in $37(63 \%)$, and in group-2, it was conservative in 8 cases $(11 \%)$ and radical in $65(89 \%)$. Table-1 represents the tumoral characteristics in the 2 groups.

\section{Groups of Patients According to Tumoral Diameter}

Group-1 included the total of 65 patients (47\%), with mean age of 59.2 years (38 to 76 years); follow up varied from 2 to 138 months (median $=36$ months), and the mean size of the tumor was $2.5 \pm$ $0.7 \mathrm{~cm}$. Group- 2 was composed of 73 patients (53\%), with mean age of 57.9 years (9 to 87 years); follow up varied from 2 to 111 months (median $=31$ months), and the mean size of the tumor was $5.3 \pm 1.0 \mathrm{~cm}$.

\section{Tumor Characteristics}

In group-1, 11 patients (17\%) presented highgrade tumors (III and IV), and in group-2, 47 patients $(64 \%)$ presented high-grade tumors $(\mathrm{p}=0.01) ; 2 \mathrm{pa}-$

Table 1 - Characteristics of tumors.

\begin{tabular}{lcccccc}
\hline & N (\%) & High-Grade (\%) & $\begin{array}{c}\text { Microvascular } \\
\text { Invasion (\%) }\end{array}$ & Sarcomatous (\%) & $\begin{array}{c}\text { Positive } \\
\text { Lymph nodes (\%) }\end{array}$ & Size (cm) \\
\hline $\begin{array}{c}\text { Group 1 } \\
<4 \mathrm{~cm}\end{array}$ & $65(47)$ & $11(17)$ & $2(3)$ & 0 & 0 & $2.5 \pm 0.7$ \\
$\begin{array}{c}\text { Group 2 } \\
4-7 \mathrm{~cm}\end{array}$ & $73(53)$ & $47(64)$ & $17(23)$ & $4(5.5)$ & $2(1.4)$ & $5.3 \pm 1.0$ \\
\hline
\end{tabular}


tients of group-1 (3\%) presented microvascular invasion, while $17(23 \%)$ patients in group-2 presented microvascular invasion $(\mathrm{p}=0.001)$. Lymph nodes involvement occurred in 2 patients (1.4\%) from group2 , not occurring in any patient of group-1 $(\mathrm{p}=0.1)$.

\section{Cell Types}

There was homogeneous distribution in relation to cellular types. Clear cell tumor was the predominant in both groups, and sarcomatous degeneration was present only in group-2, in 4 patients $(5.5 \%)$ $(\mathrm{p}=0.05)$.

\section{Recurrence of Disease}

In group-1, there was no tumoral recurrence. In group-2, it happened in 8 of 73 patients (11\%), 15 months after surgery in average (5 to 45 months).

\section{Survival}

From the 8 patients with recurrence, 4 ended in obit during follow up (Table-2). The disease-free survival curve was of $100 \%$ and $81 \%(\mathrm{p}=0.008)$ for groups-1 and 2, respectively (Figure-1). There was no loss in follow up for any patient.

\section{DISCUSSION}

This work has demonstrated that RCC smaller than $4 \mathrm{~cm}$ are in their majority low-grade tumors, rarely present microvascular invasion, do not present sarcomatous degeneration, nor involved lymph nodes, having probability of survival equivalent to $100 \%$ in 3 years.

The behavior of small volume renal tumors remains unknown (9), but tumoral size is related to malignant potential (10). The size of neoplasia as prognostic factor for localized tumors is generating controversy (8). The incidence of tumors with less than $4 \mathrm{~cm}$, from $28 \%$ in 1985 increased to $61 \%$ in 1995 (9), as well as the number of renal conservative surgeries increased, what therefore makes relevant the study of biological behavior of this subgroup, which includes RCC with less than $7 \mathrm{~cm}$. Targonski et al. (7), studied 93 individuals with RCC, and concluded that patients with tumors smaller than $5 \mathrm{~cm}$ presented greater survival. In another study, a more favorable evolution has been observed in patients with tumors smaller than $5.5 \mathrm{~cm}$ (9). Lee et al. (10), analyzing 252 renal tumors smaller than 4 $\mathrm{cm}$, observed a high incidence of multimodality and metastasis in tumors from 2.1 to $4 \mathrm{~cm}$, contra-indicating conservative surgery for tumors greater then $2 \mathrm{~cm}$. This result is contrary to the majority of works on conservative surgery for RCC, in which lesions smaller than $4 \mathrm{~cm}$ treated with partial or radical surgery presented similar evolution $(4,5,9)$. Other controversial work was accomplished by Belldegrun et al. (11), which declares that patients treated with conservative and radical surgery present similar evo-

Table 2 - Demographic data for the 8 recurrences in group-2.

\begin{tabular}{lccccccc}
\hline Sex & Age & $\begin{array}{c}\text { Tumoral } \\
\text { Size }(\mathbf{c m})\end{array}$ & Grade & $\begin{array}{c}\text { Microvascular } \\
\text { Invasion }\end{array}$ & $\begin{array}{c}\text { Cellular } \\
\text { Type }\end{array}$ & $\begin{array}{c}\text { Positive } \\
\text { Lymph nodes }\end{array}$ & Evolution \\
\hline M & 61 & 4 & high & + & sarcomatous & - & death \\
F & 65 & 5 & low & - & papillary & + & death \\
M & 56 & 5,5 & high & + & sarcomatous & - & death \\
M & 75 & 5,5 & high & - & papillary & - & WED \\
M & 54 & 6 & high & + & papillary & + & WED \\
M & 46 & 7 & high & + & clear cell & - & WED \\
M & 51 & 7 & high & - & clear cell & - & death \\
M & 60 & 7 & low & - & clear cell & - & WED \\
\hline
\end{tabular}

WED = With Evidence of Disease 


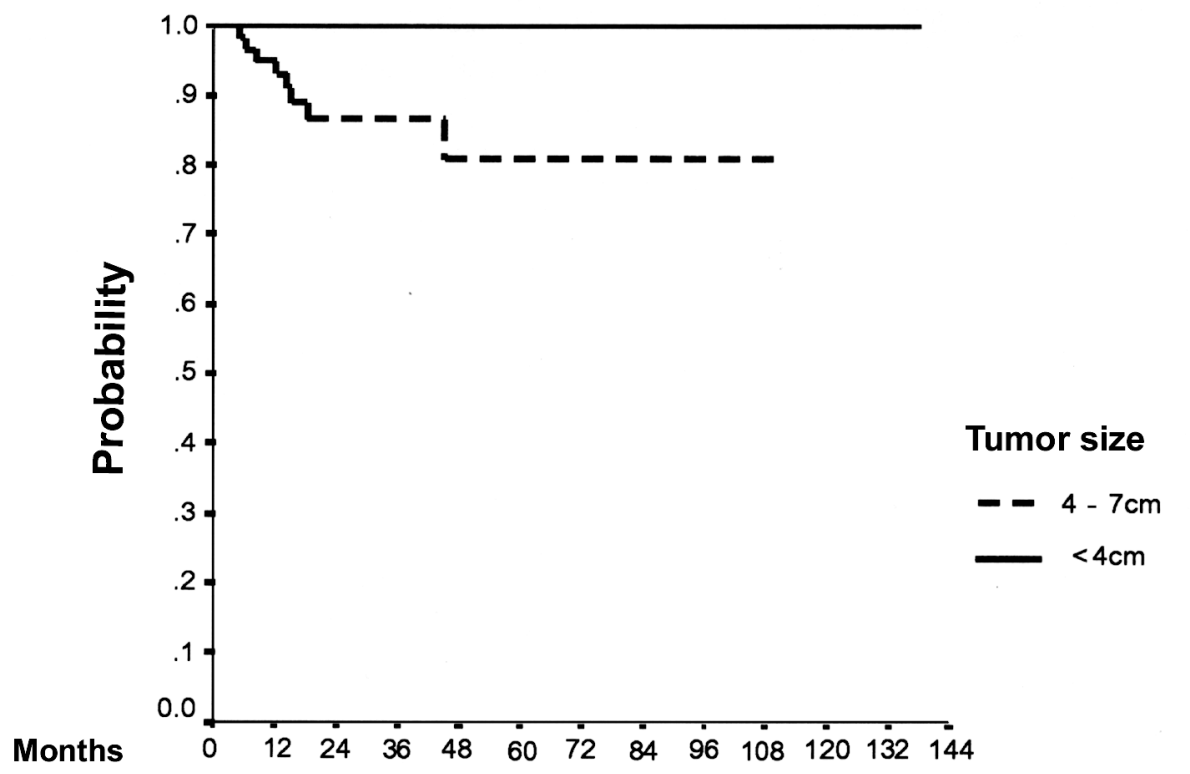

\section{Recurrence}

Figure 1 - Disease-free survival curves $(p=0.008)$.

lution, with tumors smaller than $4 \mathrm{~cm}$, as wells as between 4 and $7 \mathrm{~cm}$.

RCC staging is one of the most important prognostic factors $(12,13)$, being a crucial point in the determination of therapeutic approach. With the objective of universalizing the TNM classification for RCC, there have been several changes already, being it presently in the fifth edition (3). Due to the fact of believing that the behavior of stage $\mathrm{T} 1$ is not completely know, (14) various proposals aroused as cutting point for stage T1: $4 \mathrm{~cm}(4,5), 4.5 \mathrm{~cm} \mathrm{(6),} 5 \mathrm{~cm}(7)$ and $5.5 \mathrm{~cm} \mathrm{(8),}$ justifying the subdivision of clinical stage $\mathrm{T} 1$ for a better selection of patients for conservative surgery. On the other hand, maintenance of current TNM is also defended (15,16). Results obtained in 1997 (17) and others, more recent $(4,5)$, propose the modification of current TMN classification to T1a for tumors smaller than $4 \mathrm{~cm}$, and T1b for tumors between 4 and $7 \mathrm{~cm}$, what would allow for a better prediction of specific and disease free cancer survival, thus optimizing the prog- nostic (4). Based in previous studies, we share the opinion that tumors smaller than $4 \mathrm{~cm}$ are less aggressive.

It is attributed to high-grade tumors a 5 years survival of $46 \%$ (18), but the presence of intratumoral microvascular invasion gives chance of disease progression in half of the cases (19). In our case, high nuclear degree and microvascular invasion were predominant in group-2, having statistical significance when compared to the group of patients having tumors smaller than $4 \mathrm{~cm}$ (group1). Another data that is very important is that positive lymph nodes and sarcomatous pattern has only happened in group-2. It is well known that sarcomatous degeneration gives mean survival of 49 months for tumors smaller than $7 \mathrm{~cm}$ confined to the kidney, while lymph node invasion results in a 5 years survival equivalent to $33 \%$ (18).

Specific cancer survival for patients with stage T1 tumors in 10 years varies from $86 \%$ to 
92\%. Nevertheless, when current T1 is subdivided into tumors smaller than $4 \mathrm{~cm}$, survival in 10 years varies from $97 \%$ to $99 \%$; but for tumors between 4 and $7 \mathrm{~cm}$, survival was between $76 \%$ and $84 \%$ (4). Our work has shown survival free of disease of $100 \%$ for group-1, and $81 \%$ for group-2, showing a clear correlation between tumor size, disease recurrence, and deaths for tumors greater than $4 \mathrm{~cm}$. Survival of patients with disease recurrence is of 3 years, in spite of immunotherapy (20).

Therefore, we believe that the subdivision into $\mathrm{T} 1 \mathrm{a}$ and $\mathrm{T} 1 \mathrm{~b}$, with cutting point of $4 \mathrm{~cm}$, is needed for perfecting the current TNM system, for it creates a more homogeneous group, practically without worse prognostic factors. Our results suggest that tumors greater than $4 \mathrm{~cm}$ are potentially more aggressive than smaller tumors, and are not supposed to be in the same stage of disease.

As a future perspective, we believe that this series will confirm the international studies defending the subdivision of present clinic stage T1 (TNM 1997).

\section{CONCLUSION}

Current RCC classification, stage T1, includes tumors of different evolution, being recommendable the stratification into T1a and T1b with a cut level of $4 \mathrm{~cm}$, in order to homogenize the groups and have a better correlation with prognosis.

\section{REFERENCES}

1. Jayson M, Sanders H: Increased incidence of serendipitously discovered renal cell carcinoma. Urology 1998; 51: 203-5.

2. Robson CJ, Churchill BM, Anderson W: The results of radical nephrectomy for renal cell carcinoma. J Urol. 1969; 101: 297-301.

3. Sobin LH, Wittekind $\mathrm{CH}$, International Union Against Center: TNM classification of malignant tumors. New York, Wiley-Liss.1997, $5^{\text {th }}$ ed., pp. 180-2.

4. Igarashi T, Tobe T, Nakatsu HO, Suzuki N, Murakami S, Hamano M, et al.: The impact of a $4 \mathrm{~cm}$ cutoff point for stratification of T1NOM0 renal cell carcinoma after radical nephrectomy. J Urol. 2001; 165: 1103-6.
5. Hafez KS, Fergany AF, Novick AC: Nephron sparing surgery for localized renal cell carcinoma: impact of tumor size on patient survival, tumor recurrence and TNM staging. J Urol. 1999; 162: 1930-3.

6. Zisman A, Pantuck AJ, Chao D, Dorey F, Said JW, Gitlitz BJ, et al.: Reevaluation of the 1997 TNM classification for renal cell carcinoma: T1 and T2 cutoff point at 4,5 rather $7 \mathrm{~cm}$. better correlates with clinical outcome. J Urol. 2001; 166: 54-8.

7. Targonski PV, Frank W, Stuhldreher D, Guinam PD: Value of tumor size in predicting survival for renal cell carcinoma among tumors, nodes and metastases stage 1 and stage 2 patients. J Urol. 1994; 152: 138992.

8. Kinouchi T, Saiki S, Meguro N, Maeda O, Kuroda M, Usami M, et al.: Impact of tumor size on the clinical outcomes of patients with Robson stage I renal cell carcinoma. Cancer. 1999; 85: 689-95.

9. Wunderlich H, Reichelt O, Schumann S, Schlichter A, Kosmehl H, Werner W, et al.: Nephron sparing surgery for renal cell carcinoma $4 \mathrm{~cm}$. or less in diameter: indicated or under treated? J Urol. 1998; 159: $1465-9$.

10. Lee CT, Katz J, Shi W, Thaler HT, Reuter VE, Russo $P$ : Surgical management of renal tumors $4 \mathrm{~cm}$. or less in a contemporary cohort. J Urol. 2000; 163: 730-6.

11. Beldegrun A, Tsui KH, deKernion JB, Smith RB: Efficacy of nephron-sparing surgery for renal cell carcinoma: analysis based on the new 1997 tumornode-metastasis staging system. J Clin Oncol. 1999; 17: 2868-75.

12. Ljunberg B, Alandari FI, Rasmuson T, Roos G: Follow up guidelines for nonmetastatic renal cell carcinoma based on the occurrence of metastases after radical nephrectomy. BJU Int. 1999; 84: 405-11.

13. Russo P: Renal cell carcinoma: presentation, staging, and surgical treatment. Semin Oncol. 2000; 27: 16076.

14. Cheville JC, Blute ML, Zincke H, Lohse CM, Weaver AL: Stage pT1 conventional (clear cell) renal cell carcinoma: pathological features associated with cancer specific survival. J Urol. 2001; 166: 453-6.

15. Moch H, Gasser T, Amin MB, Torhorst J, Sauter G, Mihatsch MJ: Prognostic utility of the recently recommended histologic classification and revised TNM staging system of renal cell carcinoma. Cancer. 2000; 89: 604-14.

16. Javidan J, Stricker HJ, Tamboli P, Amin MB, Peabody JO, Deshpande A, et al.: Prognostic significance of 
1997 TNM classification of renal cell carcinoma. J Urol. 1999; 162: 277-81.

17. Guinam P, Sobin LH, Algaba F, Badellino F, Kameyama S, MacLennan G, et al.: TNM Staging of renal cell carcinoma: Workgroup No. 3. Union International Contre le Cancer (UICC) and the American Joint Committee on Cancer (AJCC). Cancer. 1997; 80: 992-3.

18. Pantuck AJ, Zisman A, Belldegrun AS: The changing natural history of renal cell carcinoma. J Urol. 2001; 166: 1611-23.
19. Dall'Oglio MF, Srougi M, Gonçalves PD, Leite KM, Scortegagna Jr E, Hering F: Significance of intratumoral microscopic vascular invasion in patients with renal cell carcinoma. Int Braz J Urol. 2002; 28: 102-8.

20. Figlin RA, Pierce WC, Kaboo R, Tso CL, Moldawer N, Gitlitz B, et al.: Treatment of metastatic renal cell carcinoma with nephrectomy, interleukin-2 and cytokine-primed or CD-8 (+) selected tumor infiltrating lymphocytes from primary tumor. J Urol. 1997; 158: 740-5.

Received: December 11, 2002

Accepted after revision: March 24, 2003

\author{
Correspondence address: \\ Dr. Marcos Francisco Dall'Oglio \\ Rua Manoel da Nóbrega, 853 casa 22 \\ São Paulo, SP, 04001-084, Brazil \\ Fax: + $55113885-0658$ \\ E-mail: marcosdalloglio@uol.com.br
}

\section{EDITORIAL COMMENT}

The factors that are most important for staging renal cell carcinoma (RCC) are the tumoral size and the existence of metastasis in lymph nodes. For the kidney, as well as for the urinary bladder, microvascular invasion should occur, but it does not change the stage, differently to what happens with the testicle.

Partial nephrectomy, currently, has been the preferable treatment of these tumors. Tumor size and location are limiting factors for the procedure. With the introduction of laparoscopic nephrectomy, these aspects became even more important.

Subdivision of stage T1 in T1a and T1b $(<4$ $\mathrm{cm}$ and 4 to $7 \mathrm{~cm}$ ) is very important for surgical success and tumor recurrence.

Presently, it is well determined that the surgical margin is an important factor, but there is no consensus on the thickness of this margin. The literature refers it as $0.5 \mathrm{~cm}$ at least, 0.5 to $1.5 \mathrm{~cm}, 1 \mathrm{~cm}$, $1.5 \mathrm{~cm}$, and a region of macroscopically normal renal tissue (1).

The high-grade of the tumor, as well as sarcomatous degeneration are important factors for worse prognosis. In the present work, there was not any case of sarcomatous type in group-1 (tumors smaller than $4 \mathrm{~cm}$ ).

Fuhrman nuclear grading (FNG) (2) is correlated to TNM staging in relation to the progression of neoplasia, i.e., as FNG increases, greater are the chances of progression. On the other hand, the thickness of surgical resection margin did not show correlation with tumoral progression (1). The grading of nuclear alterations of Fuhrman (FNG) is probably the most used parameter as indicator of tumoral prognosis (3). 
In this way, the association of worse prognosis factors like FNG with RCC greater than $4 \mathrm{~cm}$, strengthens the recommendation of subdividing the TNM classification into T1a and T1b for renal carcinoma.

\section{References}

1. Castilla EA, Liou LS, Abrahams NA, Fergany AMR, Rybicki LA, Myles J, et al.: Prognostic importance of resection margin width after nephron-sparing

\section{EDITORIAL COMMENT}

In the present article, doctor Dall' Oglio and co-workers found that renal cell carcinomas with less than $4 \mathrm{~cm}$ in diameter are in general low-grade tumors, do not present microvascular invasion, do not present sarcomatous differentiation and do not involve lymph nodes, presenting a survival probability of $100 \%$ in 3 years, different from those surgery for renal cell carcinoma. Urology 2002; 60: 993-997.

2. Furhman S, Lasky L, Limas C: Prognostic significance of morphologic parameters in renal cell carcinoma. Am J Surg Pahol. 1982; 6: 655-663.

3. Levin AHS, Myles AJL: The Pathology of Renal Neoplasms. In: Bulowski ARM and Novick AC (eds.): Renal Cell Carcinoma: Molecular Biology, Immunology and Clinical Managment. Totowa, Humana Press. 2000, pp. 15-38.

Dr. Nelson Rodrigues Netto Jr. Professor and Chairman, Division of Urology State University of Campinas, Unicamp Campinas, São Paulo, Brazil

tumors between 4 and $7 \mathrm{~cm}$ in diameter. Therefore, this is a very much timely and welcome publication because it is one more validation of the very recent 2002 TNM staging modification of renal tumors on which the pT1 stage was substratified in pT1a (tumors less than $4 \mathrm{~cm}$ ) and pT1b (tumors from 4 to $7 \mathrm{~cm})$.

Dr. Francisco J.B. Sampaio Professor and Chair, Urogenital Research Unit State University of Rio de Janeiro Rio de Janeiro, Brazil 